\title{
SLAVERY UNDER THE EUROPEAN CONVENTION ON HUMAN RIGHTS AND THE JUS COGENS PROHIBITION OF HUMAN TRAFFICKING
}

\author{
Stefan Kirchner ${ }^{*}$ and Vanessa M. Frese ${ }^{\#}$
}

\begin{abstract}
Human trafficking for purposes of sexual and other forms of slavery continues to pose a major threat to the human rights and human dignity of many persons. This is particularly the case for young women from Eastern European nations. Not to be confused with human smuggling and undocumented immigration, human trafficking usually aims at exploitation, often through slavery in the form of un-oder underpaid domestic work or forced prostitution. The European Convention on Human Rights (ECHR) as well as jus cogens outlaw slavery. In this article it is shown by the authors that human trafficking - although not explicitly dealt with in the ECHR - is also prohibited if it aims at creating or maintaining a situation of slavery. Indeed, it is then prohibited by jus cogens and states have a positive obligation to combat human trafficking effectively. Many states fail to do so, showing that this problem is one of law enforcement rather than of creating effective legal norms since those already exist.
\end{abstract}

\section{KEYWORDS}

Human trafficking, slavery, European Convention on Human Rights, jus cogens.

\footnotetext{
* Associate Professor for Fundamental and Human Rights, University of Lapland, Faculty of Law, P. O. Box 122, 96101 Rovaniemi, Finland, Email: stefan.kirchner@ulapland.fi,

\# Law student, University of Fribourg, Avenue de L'Europe 20, 1700 Fribourg, Switzerland; International Law Research Intern, humanrightslawyer.eu.
} 


\section{INTRODUCTION}

For many people who leave the Middle East or Africa, Europe is the destination of their dreams. Often fueled by unrealistic expectations, they risk their lives to escape war, persecution or poverty. For thousands, the Mediterranean Sea becomes a grave without a gravestone. ${ }^{1}$ Within Europe, many from the formerly communist countries in the East move to the West in the hopes of a better life. In many cases is the life they find not better than the one they left behind; all too often, it is one of exploitation and violence. In particular young women are at risk of being forced into sexual slavery.

The understanding of human trafficking for the purpose of sexual slavery which underlies this text is the view that actions which are essential for establishing or maintaining the slavery in questions are also slavery and hence equally prohibited. This includes human trafficking. Likewise it includes e.g. violent acts against victims of slavery. Such acts forming part of slavery states have an obligation to prevent them.

Oftentimes, human trafficking is confused with human smuggling. ${ }^{2}$ The later refers to the illegal entry into a state ${ }^{3}$ while the former is characterized by the abuse of power differentials for exploitative purposes. ${ }^{4}$ While often mistakenly thought to be a thing of the past, slavery remains an important issue. Indeed, it is thought that the late 20th and early 21 st century has seen more slaves than any other time in human history. ${ }^{5}$ In this article, it will be shown how the European Convention on Human Rights $(\mathrm{ECHR})^{6}$ protects against human trafficking for the

\footnotetext{
${ }^{1}$ Maria Margaronis, 'The Mediterranean Has Become the Grave of Migrants', Thenation.Com, 9 May 2014, available online at $<$ http://www.thenation.com/blog/179776/mediterranean-has-become-gravemigrants $>$.

2 On the difference between trafficking and smuggling of humans see Marina Elefante, 'Slave Women: The Italian Legal Response to the International Trafficking of Women' (2007) 1 The Protection Project Journal of Human Rights and Civil Society 1, 2.

${ }^{3}$ Ibid 3.

${ }^{4}$ For a more detailed description, see Elefante (n 2) 3.

${ }^{5}$ Terrence McNally, 'There Are More Slaves Today than at Any Time in Human History', Alternet.org, 12 January 2015, available online at http://www.alternet.org/civil-liberties/there-are-more-slaves-today-any-timehuman-history.

${ }^{6}$ Council of Europe, European Convention for the Protection of Human Rights and Fundamental Freedoms, as amended by Protocols Nos. 11 and 14, 4 November 1950, ETS 5, available online at
} 


\section{SLAVERY UNDER THE EUROPEAN CONVENTION ON HUMAN RIGHTS}

purposes of slavery but also that in human trafficking can fall within the scope of the jus cogens prohibition of slavery under general Public International Law.

\section{SLA VERY}

The ECHR does not define the term "slavery". ${ }^{7}$ It does not have to do so. While in many way reminiscent of a self-contained regime, the ECHR is still an international treaty and as such its interpretation can be informed by international law in general for example the 1924 Slavery Convention. ${ }^{8}$ For the purposes of the convention, the term "slavery" is to be understood as "the status or condition of a person over whom any or all of the powers attached to the right of ownership are exercised".

\subsection{Slavery in general Public International Law}

Understanding international law requires understanding its historic background. ${ }^{10}$ Slavery has been around for millennia and has been outlawed in international law for long. The intercontinental slave trade of the colonial era led to efforts to outlaw slavery. ${ }^{11}$ Jus cogens rules are rules, which have to be obeyed at all times. ${ }^{12}$ Today, the prohibition of slavery is undoubtedly prohibited under international law ${ }^{13}$; indeed the international law prohibition of slavery is a norm of jus cogens. ${ }^{14}$ In

http://www.echr.coe.int/Documents/Convention_ENG.pdf.

${ }^{7}$ Christoph Grabenwarter, Europäische Menschenrechtskonvention (3rd ed, Beck 2008) 55.

${ }^{8}$ United Nations, Slavery Convention, 25 Sept 1924, UNTS 60, 254.

${ }^{9}$ Grabenwarter (n 7) 55.

${ }^{10}$ Elefante (n 4) 7. On the development of anti-slavery law on the international level in the 18th century, see Michael Haas, International Human Rights - A Comprehensive Introduction (1st ed, Routledge 2008) 49 and 70.

${ }^{11}$ David J. Bederman, Globalization and International Law (1st ed, Palgrave, 2008) 35; Antonio Cassese, International Law (1st ed, Oxford 2001) 350; Christopher Joyner, International Law in the 21st Century - Rules for Global Governance (1st ed, Rowman \& Littlefield 2005) 136.

${ }^{12}$ See entry "jus cogens" in the Cornell University Law School Legal Dictionary, Legal Information Institute, available online at http://www.law.cornell.edu/wex/jus_cogens.

${ }_{13}$ Thomas Buergenthal et al, Grundzüge des Völkerrechts (1st ed, CF Müller 1988) 117.

${ }^{14}$ Rafael Nieto-Navia, 'International Peremptory Norms (Jus Cogens) and International Humanitarian Law', available online at 
addition, it is not only an obligation erga omnes ${ }^{15}$ (an obligation of all subjects of international law ${ }^{16}$ towards all other subjects of international law) but also omnium, meaning that slavery is prohibited for everybody, individuals, states, corporations and all other entities, persons and groups of persons. In addition, there is a rule of jus cogens which obliges all states to take positive action and fight slavery.

\subsection{Slavery and the Law of the Sea}

In the 1982 Law of the Sea Convention ${ }^{17}$ (LOSC), this duty has been codified in Article 99, which follows similar rules which were contained in international treaties ${ }^{18}$ against the trade in slaves. ${ }^{19}$ Since the 19th and early 20th century ${ }^{20}$ a number of such treaties have been concluded, ${ }^{21}$ leading to the current situation that slavery is absolutely illegal under international law. Article 110 (1) (b) LOSC provides the legal powers to fulfill this duty by mentioning the reasonable suspicion of trade in slaves by use of a ship as one of the exceptional justifications for boarding a ship on the high seas. Due to the jus cogens nature of this obligation, lit. (b) of this norm would not have necessary ${ }^{22}$ as it would have followed from the jus cogens duty to fight slavery that such actions may be taken. Rather than providing an argument against such a duty, lit. (b) LOSC has to be seen in the context of para. 1 of Article 110 LOSC, which names all

http://www.iccnow.org/documents/WritingColombiaEng.pdf.

${ }^{15}$ For an overview over the arguments in favor of understanding rules concerning the protection of women as obligations erga omnes, see Farhad Malekian, 'The Laws Governing Crimes against Women Constituting Obligatio Erga Omne', in David Wingeate Pike (ed), Crimes against Women (1st ed, Nova 2011) 3, 15, with further references.

${ }^{16}$ See Stephan Hobe / Otto Kimminich, Einführung in das Völkerrecht (8th ed, CF Müller 2004) 64.

${ }^{17}$ United Nations, Convention on the Law of the Sea, UN Doc. A/CONF. 62/122, (1982) 21 International Legal Materials 1261.

${ }^{18}$ For a short overview, see Peter Malanczuk, Akehurst's Modern Introduction to International Law (1st ed, Routledge 1997, reprint 1998) 21.

${ }^{19}$ Ibid 188.

${ }^{20}$ Thomas G Weiss et al, The United Nations and Changing World Policies (5th edn, Westview 2007) 145.

${ }^{21}$ See in detail Nina Lassen, 'Article 4', in Gognundur Alfredsson et al (eds), The Universal Declaration of Human Rights: A Common Standard of Achievement (1st edn, Springer Netherland 1999) 87, and Knut Ipsen, Völkerrecht (5th edn, Beck 2004) 776, with further references.

${ }^{22}$ For the opposite view, see DJ Harris, Cases and Materials on International Law (5th edn, Sweet \& Maxwell 1998) 431. 


\section{SLAVERY UNDER THE EUROPEAN CONVENTION ON HUMAN RIGHTS}

grounds for boarding a ship on the high seas while for example para. 2 of the same norm explains the way in which such boarding may be undertaken etc.

\subsection{Slavery as an International Crime.}

Like a pirate, a slave trader is hostis humani generis, an enemy of all mankind. It can therefore be argued that there is also a universal obligation incumbent upon everybody to fight slavery. Slavery is "a crime under modern international law". ${ }^{23}$ International criminal law does not cover human trafficking for purposes of forced prostitution. ${ }^{24}$ This makes it necessary for states, and indeed for everybody, to take the necessary action to fight slavery. For states this means legislating and enforcing domestic laws which outlaw slavery. For individuals this can mean petitioning your state to actually create such laws or to enforce them better where this is not the case and to inform the authorities of cases of slavery should they become known.

\subsection{Slavery and the European Convention on Human Rights}

Human rights have sometimes been accused of becoming unclear or suffering from far-reaching demands which lead to a "[r]ights [i]nflation". ${ }^{25}$ The issue of slavery is at the exact opposite end of the spectrum in this regard: while de jure slavery is absolutely prohibited, it are de facto the victims who are in the weakest position and least able to speak out and demand their rights. This makes it necessary for human rights activists to take action and to engage in law fare for the purpose of ending slavery not only on paper but also in fact. From the perspective of European human rights law, slavery often receives little attention due to the small number of cases, which have been decided by the European Court of Human Rights. ${ }^{26}$ Until v Cyprus and Russia, ${ }^{27}$ the leading cases under Article 4 ECHR seem to have been three cases against Belgium which did not involve human trafficking: In De Wilde, Ooms and Versyp $v$

\footnotetext{
23 Joyner (n 11) 136.

${ }^{24}$ Joyner (n 11) 137.

${ }^{25}$ George Letsas, A Theory of Interpretation of the European Convention on Human Rights (1st edn, Oxford University Press 2007) 120.

${ }^{26}$ Mark W Janis et al, European Human Rights Law - Text and Materials (3rd edn, Oxford University Press 2008) 231.

${ }^{27}$ European Court of Human Rights, Rantsev v Cyprus and Russia, application no. 25965/04, judgment of 7 January 2010.
} 
Belgium..$^{28}$ In the case of Van Droogenbroeck v Belgium ${ }^{29}$ "the applicant submitted that the fact that he had been placed at the disposal of the Government as a recidivist, had reduced him to a condition of servitude, since in fact he was subject to arbitrary supervision by the administrative authorities." ${ }^{30}$ Back then, the Commission outlined the elements of servitude in the negative while excluding Mr. Van Droogenbroeck's claim $^{31}$, specifically, "because the measure was one of limited duration only, was subject to judicial review and did not affect the legal status of the person in question." ${ }^{32}$ Van der Mussele v Belgium ${ }^{33}$ concerned the duty of a trainee lawyer to represent impoverished clients for free. ${ }^{34}$ The applicant in Karlheinz Schmidt v Germany ${ }^{35}$ complained of inequality before the law. While relating to legitimate concerns of the applicants, these cases seem far removed from the reality of slavery many victims experience everyday all over Europe. Siliadin $v$ France dealt with the exploitation of a girl under the age of 18 from Togo who was in France without a residence permit and who had been exploited there as a domestic worker and was handed over from one family to the next. ${ }^{36}$ It was in Rantsev $v$ Cyprus and Russia ${ }^{37}$ that the reality of many young women from Eastern Europe became relevant in the halls of Strasbourg.

${ }^{28}$ European Court of Human Rights, De Wilde, Ooms and Verysp v Belgium, application nos. 2832/66; 2835/66; 2899/66, judgment of 18 June 1971.

${ }^{29}$ European Court of Human Rights, Van Droogenbroeck v Belgium, application no. 7906/77, judgment of 24 June 1982.

${ }^{30}$ Leo Zwaak, 'Freedom from Slavery, Servitude and Force or Compulsory Labour' in Pieter van Dijk et al (eds), Theory and Practice of the European Convention on Human Rights (1st edn, Intersentia 2006) 443, 444.

${ }^{31}$ Van Droogenbroeck v Belgium (n 29) [58].

${ }^{32}$ Zwaak (n 30) 444; Van Droogenbroeck v Belgium (n 29).

${ }^{33}$ European Court of Human Rights, Van der Mussele v Belgium, application no. 8919/80, judgment of 23 November 1983.

${ }^{34}$ Ibid.

${ }^{35}$ European Court of Human Rights, Karlheinz Schmidt v Germany, application no. 13580/88, judgment of 18 July 1994.

${ }^{36}$ European Court of Human Rights, Siliadin v France, application no. 73316/01, final judgment of 26 October 2005; Roberta Avellino, 'Trafficking in Persons and the European Convention of Human Rights', in Strasbourg Observer, 26 October 2011, available online at

http://www.internationallawobserver.eu/2011/12/07/council-of-europe-fightingtrafficking-in-persons/, 3, on the efforts of the COE; ibid, 12, on Siliadin v France.

${ }^{37}$ Rantsev (n 27). 


\section{SLAVERY UNDER THE EUROPEAN CONVENTION ON HUMAN RIGHTS}

The court's view ${ }^{38}$ therefore does not go far enough. The decision in Rantsev $v$ Cyprus and Russia was an important landmark - not only in terms of the application of Article 4 ECHR to human trafficking, but also a problematic judgment. By allowing for limitations to the general duty to fight human trafficking the Court overlooks that while slavery and human trafficking are distinct concepts, human trafficking can be an aspect of slavery. This was also the case in Rantsev In this case, the duty to fight human trafficking is a part of the obligation to fight slavery. Assuming that the European Court of Human Rights did not intend to weaken either the jus cogens prohibition of slavery or the concept of jus cogens as a whole, it appears that the Court, in following for the possibility that the obligation to fight human trafficking for the purpose of sexual slavery is not "absolute" 39 , has overlooked that, while slavery and human trafficking normally are two different legal categories, here the latter is an essential element of the former and is therefore to be treated as such. In the case of slavery this means an absolute jus cogens and erga omnes obligation to combat it.

In Rantsev the Court went into more detail than in the Siliadin case $^{40}-$ but it did not yet go far enough: "Although the link between trafficking and slavery has been clearly acknowledged by the European Court of Human Rights, that court has shied away from stating explicitly that trafficking amounts to enslavement". ${ }^{41}$ Should the Court have to deal with a case like Rantsev v Cyprus and Russia in the future, it would be welladvised to clarify the extent of what constitutes slavery.

In VF $v$ France $^{42}$ the Court decided the applicant to be manifestly illfunded because the applicant was thought not to haven proven that the police should have known that the applicant was a victim of human trafficking and despite shortcomings in the domestic legal system (covering the protection against human trafficking) she was to be deported there to her home country. ${ }^{43}$ A lack of evidence was also the reason why

${ }^{38}$ Rantsev (n 27) [287], see also Ryszard Piotrowicz, 'States' Obligations Under Human Rights Law Towards Trafficking in Human Beings: Positive Developments in Positive Obligations' (2012) 24:2 International Journal of Refugee Law 181, 198.

${ }^{39}$ Ibid.

${ }^{40}$ Ibid 200.

${ }^{41}$ Ibid 201.

${ }^{42}$ European Court of Human Rights, VF c France, application no 7196/10.

${ }^{43}$ Ibid. 
the application in $M$. and others $v$ Italy and Belgium was dismissed as illfounded. ${ }^{44}$

In F.A. v United Kingdom the application was concluded inadmissible for failure to lodge an appeal in the domestic court system. ${ }^{45}$ This highlights a problem, which is often overlooked. Victims of human trafficking often lack access to legal counsel. Often their identification documents have been taken away and in many cases they never have a real chance of learning the language of the country to which they have been trafficked. The state's obligation to fight slavery is not only negative but - as already follows from the general rules of international law outlined earlier - positive in nature. States must take effective action to fight slavery. Accordingly, the United Kingdom in C.N. $v$ United Kingdom was found to have violated Art. 4 ECHR due to a lack of effective domestic anti-slavery legislation. ${ }^{46}$ While slavery is outlawed on paper, this prohibition is not enforced effectively. While efforts against human trafficking are made by many European states, including the enforcement of criminal law, the duty of states goes beyond the criminal law dimension. States' obligations e.g. under Article 6 ECHR, which guarantees the right to a fair trial, also include a duty to enable access to justice. This includes not only a necessity for the establishment of legal aid systems but also requires states to ensure that everybody has the possibility to retain legal counsel - including victims of human trafficking.

While we all have core human rights qua human, ${ }^{47}$ there is a contradiction between the universality of human rights ${ }^{48}$ and local conditions of enforcing them. ${ }^{49}$ If human rights would have their origin in society, they would be local because when societies became aware of human rights there was no global society. How then do we explain the Geltungsgrund of Human Rights? Neither presumption is correct: there has always been a global society in the sense of Francisco de Vitoria's

\footnotetext{
${ }^{44}$ European Court of Human Rights, $M$ and others $v$ Italy and Bulgaria, application no 40020/03, final judgment of 17 December 2012.

${ }^{45}$ European Court of Human Rights, FA v the United Kingdom, application no. 20658/11.

${ }^{46}$ European Court of Human Rights, $C N v$ the United Kingdom, application no. 4239/08, final judgment of 13 February 2013.

${ }^{47}$ Mark Gibney, International Human Rights Law - Returning to Universal Principles (1st edn, Rowman \& Littlefield 2008) 3.

${ }^{48}$ Ibid.

${ }^{49}$ Christoph Menke/Arnd Pollmann, Philosophie der Menschenrechte - zur Einführung (1st edn, Junius 2008) 39.
} 


\section{SLAVERY UNDER THE EUROPEAN CONVENTION ON HUMAN RIGHTS}

totus orbis ${ }^{50}$ - but it would only have been necessary for the emergence of human rights in so far as a right require an other in relation to whom to claim it. Even the smallest groups of humans formed a society in thus widest sense of the term. There have been rights far as long as there have been humans, even before there were concepts or words to describe them. These (proto-) rights include the right to life and the right to be free, not enslaved. These rights follow from the most basic desires of every human, from our nature. In this sense, they are natural rights. Later, other rights gained a status of similar importance and the development of language and laws further strengthened the awareness of rights. ${ }^{51}$

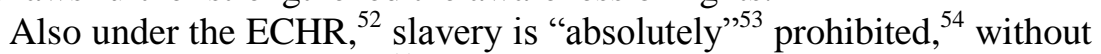
any room for justifications. ${ }^{55}$ Article 4 (1) ECHR prohibits "slavery or servitude" while under para. 2 "[n]o one shall be required to perform forced or compulsory labour", which is defined further in para. 3. Servitude is not the same as slavery. ${ }^{56}$ While "servitude implies being compelled to live on someone else's property as well as being required to work." ${ }^{57}$ Slavery has not been legally defined within the context of Article 4 ECHR. ${ }^{58}$ While the European Convention on Human Rights is a selfcontained regime within international law, it remains part of public international law as a whole. Therefore the definition of slavery within Article 4 ECHR is the same as that of slavery in public international law in general.

${ }^{50}$ José Carlos Rojano Esquivel, 'Del Toto Orbis al Ordo Orbis. El pensamiento internacionalista de Fracisco de Vitoria' (2013) available online at http://biblio.juridicas.unam.mx/libros/8/3540/11.pdf.

${ }^{51}$ MENKE (n 49) 39.

${ }^{52}$ On slavery under Article 4 of the Universal Declaration of Human Rights, see Lassen (n 21) 87.

${ }^{53}$ Philip Leach, Taking a Case to the European Court of Human Rights (2nd edn, Oxford University Press, 2007) 218.

54 Ana Maria Guerra Martins, Direito Internacional dos Direitos Humanos (1st edn, Al Medina, 2013) 208.

55 Janis et al (n 26) 230; Grabenwarter, (n 7) 156.

${ }^{56}$ The same distinction is used in Article 8 of the International Covenant on Civil and Political Rights; Lassen (n 21) 93.

57 Leach (n 53) 218; European Commission of Human Rights, Van Droogenbroeck v Belgium, Application no. 7906/77, Report of 24 June 1982, 79.

${ }^{58}$ Leach (n 53) 218; Grabenwarter (n 7) 156. 
Forced and compulsory labour within the meaning of Article 4 paras. 2 and 3 ECHR can even include cases in which the victim receives some payment. $^{59}$

\section{HUMAN TRAFFICKING}

\subsection{Background}

Violence against women is a very widespread phenomenon,$^{60}$ yet there is a serious "lack of public (official) awareness". ${ }^{61}$ Even when public officials speak out against it, often not enough is being done: "Violence against women and girls continues unabated in every continent, country and culture. It takes a devastating toll on women's lives, on their families, and on society as a whole. Most societies prohibit such violence - yet the reality is that too often, it is covered up or tacitly condoned."

Gender equality is not enough to provide the protection victims of human rights need, gender neutral law (if one assumes that international human rights law is gender neutral in the first place, a notion which is being challenged ${ }^{63}$ although " $[\mathrm{w}]$ omen themselves have begun to use the "mainstream" human rights systems more effectively" ${ }^{64}$ ). While there are also male victims, human trafficking for the purpose of sexual slavery is a crime which targets mainly women. Not enforcing the prohibition of slavery effectively not only is an omission which runs counter to jus cogens obligations of states but primarily violates women's rights. The Council of Europe has fought trafficking, ${ }^{65}$ for example with the

${ }^{59}$ Leach, ibid n 53, 219; European Court of Human Rights, Van der Mussele v Belgium, application no. 8919/80, judgment of 23 November 1983, 34.

${ }^{60}$ Rhona K. M. Smith, Texts and Materials on International Human Rights (2nd edn, Taylor and Francis 2010) 704.

${ }^{61}$ Ibid 705.

${ }^{62}$ Ban Ki-Moon, quoted by Ruchi Anand, 'The Human Rights Design: A Critique of 'Universality' in a Patriarchal World', in Pike (ed) ibid ns 15, 23, 23.

${ }^{63}$ Georgina Ashworth, 'The Silencing of Women', in Tim Dunne / Nicholas Wheeler (eds), Human Rights in Global Politics (1st edn, Cambridge University Press 1999) 259, 259; for a feminist view on the Universal Declaration of Human Rights see Anand n 62) 23, 25.

${ }^{64}$ Ashworth ibid 271.

${ }^{65} \mathrm{Ibid}$; on international law as a tool to fight human trafficking in particular as it relates to modern-day slavery, see Kuanruthai Siripatthanakosol, Human Trafficking for Sexual Exploitation: The Framework of Human Rights Protection, Doctoral Thesis Newcastle Law School (2010) 77; on efforts by the Council of Europe in particular see ibid 248. 


\section{SLAVERY UNDER THE EUROPEAN CONVENTION ON HUMAN RIGHTS}

Convention on Action against Trafficking in Human Beings. ${ }^{66}$ The Conventions lays its focus on the victims; it does so with anti-trafficking actions and aims to assist and protect victims of human trafficking. In order to achieve this aim, the Convention has included in Article 5 (3) the "obligation for Parties to promote a human rights-based approach in the development, implementation and assessment of the policies and programs to prevent human trafficking". ${ }^{67}$ States are obligated to prevent human trafficking, prosecute and punish traffickers, and engage in international co-operation. 37 European countries have already submitted themselves to the Convention (including the UK) and thus have committed themselves to upholding its standards. Very important to this process is the mechanism to monitor the States' compliance with the obligations contained in the Convention. This monitoring mechanism's purpose is to ensure that the Convention's provisions do not remain a dead letter, but are effectively implemented. ${ }^{68}$

The holistic, preventative and multi-disciplinary approach of the ECHR encourages co-ordination between the various parties involved in the process. Article 5 (3) summons the State Parties to promote a human rights-based approach and use gender mainstreaming and a child-sensitive approach to the development and implementation of prevention policies and programs. ${ }^{69}$ Upping the actions taken toward prevention of trafficking in human beings is one of the five priorities of the recently published EU Strategy towards the Eradication of Trafficking in Human Beings (20122016).

\subsection{Human Trafficking under the European Convention on Human Rights}

Unlike Article 5 of the European Union's Charter of Fundamental Rights, ${ }^{70}$ Article 4 ECHR does not spell out in express terms that human trafficking is prohibited ${ }^{71}$ but that does not mean that the European

${ }^{66}$ Council of Europe, Convention on Action against Trafficking in Human Beings, 16 May 2005, CETS 197.

67 Petya Nestorova, 'Bringing Human Trafficking Out of the Shadows: Presentation by Petya Nestorova, Executive Secretary of the Council of Europe Convention on Action against Trafficking in Human Beings', 21 November 2012, 1 , available online at www.bawso.org.uk/assets/.../Petya-Presentations.doc.

${ }^{68}$ Ibid.

${ }^{69}$ Ibid.

${ }^{70}$ Ibid.

${ }^{71}$ Christoph Grabenwarter, European Convention on Human Rights (1st edn, Beck, 2014) 58. 
Convention on Human Rights would not provide protection against human trafficking - to the contrary. ${ }^{72}$

The definition of human trafficking employed by the Court is based on the Protocol to Prevent, Suppress and Punish Trafficking in Persons, Especially Women and Children ${ }^{73}$, also known as the Palermo Protocol. ${ }^{74}$ Human trafficking "aims at exploiting a person, over whom powers comparable to the right of ownership are exercised. Victims are treated and traded as goods and forced to labour - usually of sexual nature - for little or no remuneration." 75

Human trafficking has an international dimension ${ }^{76}$ but while "transnational criminal law"77 is important in the fight against human trafficking, ${ }^{78}$ it remains the responsibility of the national states to secure local law enforcement.

\subsection{Human Trafficking for Slavery - Human Trafficking as Slavery}

Since Rantsev it is clear that Article 4 ECHR protects against human trafficking $^{79}$ - but the Court went a (dramatic but necessary) step further. In the words of Christoph Grabenwarter: "By extending the scope of protection of Article 4 [ECHR] to trafficking [...], it is now possible to enforce [the rules which are reflected also by] the Palermo Protocol and the Council of Europe Convention on Action against Trafficking in Human Beings by making use of the system of legal protection of the Convention" ${ }^{80}$ Grabenwarter here refers directly to the mentioned Protocol and Convention although to be more precise what is actually enforced are the rules reflected therein, not these legal texts and obligations flowing from them. Grabenwarter seems to share this view as

${ }^{72}$ Ibid.

${ }^{73}$ United Nations, Protocol to Prevent, Suppress and Punish Trafficking in Persons, Especially Women and Children, supplementing the United Nations Convention Against Transnational Organized Crime, 15 November 2000, UNTS 2237, 319 .

${ }_{75}^{74}$ Grabenwarter (n 71) 58.

${ }^{75}$ Ibid.

${ }^{76}$ Elizabeth Ivana Yuko, Theories, Practices and Promises: Human Trafficking Laws and Policies in Destination States of the Council of Europe, LLM Thesis Dublin City University School of Law and Government (2009) 11.

${ }^{77}$ Neil Boister, 'Transnational Criminal law?' 14:5 (2003) European Journal of International Law 5953.

${ }^{78}$ Yuko (n 76) 11.

${ }^{79}$ Grabenwarter (n 71) 59.

${ }^{80}$ Ibid 58. 


\section{SLAVERY UNDER THE EUROPEAN CONVENTION ON HUMAN RIGHTS}

he continues to write that "a new obligation is imposed upon Member States [of the Council of Europe], which they have not agreed upon". ${ }^{81}$ However, we disagree within on the Geltungsgrund of this obligation. Grabenwarter continues by writing that this "new obligation" them [i.e. the states which are parties to the ECHR but not to the aforementioned Protocol and Convention] only after ratification of a corresponding additional protocol." ${ }^{, 3}$ While this is true of said legal texts, the basis for the obligation to prevent human trafficking is found not only in customary international law but in jus cogens as human trafficking is a part of slavery ${ }^{84}$ and as such absolutely outlawed. On this legal basis, all states worldwide are obliged to take positive action against slavery, including sexual slavery and the human trafficking and exploitation which come with it. As was highlighted in Rantsev $v$ Cyprus and Russia, ${ }^{85}$ this obligation is in particular incumbent on states where human trafficking begins and where exploitation happens. The obligation to fight slavery, though, is universal. In particular target countries, such as Germany (which after the legalization and regulation of prostitution under the Schröder government has become Europe's brothel ${ }^{86}$ ). This obligation is not only objective and limited to the inter-state relations between the parties to the ECHR but individuals have a right towards the state that the state takes positive action to protect individuals against human rights violations by non-state actors. ${ }^{87}$

\section{CONCLUSIONS AND OUTLOOK}

After World War II the states, which ratified the European Convention on Human Rights became models for human rights, which other states strived to emulate. Yet, today human trafficking for the purpose of slavery is a highly lucrative business. A lot has been achieved in the last

\footnotetext{
${ }^{81}$ Ibid.

${ }^{82}$ Ibid.

${ }^{83}$ Ibid 59.

${ }^{84}$ See already see Jean Allain, 'Rantsev v Cyprus and Russia: The European Court of Human Rights and Trafficking as Slavery', 10 (2010) Human Rights Law Review 546, 550 et seq.

${ }^{85}$ Rantsev (n 27) 308.

${ }^{86}$ No author named, 'Brothel Crackdown: Politicians Aim to Reform Prostitution Laws', in Spiegel Online, 22 April 2013, available online at http://www.spiegel.de/international/germany/german-coalition-backs-tougherprostitution-laws-to-curb-trafficking-a-895748.html.

87 Anne Peters, Einführung in die Europäische Menschenrechtskonvention (1st edn, Beck 2003) 15.
} 
generations but the existing system is not used effectively enough to protect everybody. The law already exists to make slavery history. What is needed now is the political will to enforce it. States, international organizations and non-governmental organizations (NGOs) ${ }^{88}$ have at their disposal "a diverse armoury of pressures against delinquent States". ${ }^{89}$ When it comes to human trafficking, though, almost all states are involved in one way or an other, often simply by turning a blind eye to the suffering of the victims. Globalization makes trafficking easier - but it also makes it easier to fight it.

Despite having been outlawed, slavery has been a part of human history for such a long time that even some of the greatest political thinkers and statesmen (and due to the discrimination of women for millennia, records are available mainly of the political thinkings of men, which might contribute to the neglect with which the issue has been treated for too long) such as Jefferson ${ }^{90}$ and John Locke ${ }^{91}$ took slavery as a given. But even in the current age of human rights, slavery continues unabated. Indeed, it is thought that there are today more slaves than at any other time in human history. ${ }^{92}$ While the increase in the overall human population might explain this phenomenon at least in part, the fact that slavery actually still exists despite generations of efforts to eliminate it, is testament to the failure of the international community. It also reflects negatively on the value of human rights to those in power: "Needless to say, human rights are still easier to endorse than to enforce. The steady stream of international conferences and conventions against genocide, slavery, the use of torture, and racism, and for the protection of women, children, and minorities show that human rights remain in need of rescue". 93

${ }^{88}$ On the important role of NGOs, see Elena Pariotti, 'Non-State Actors, International Law and Human Rights', in Sanford R Silverburg (edn), International Law - Contemporary Issues and Future Developments (1st edn, Westview 2011) 95, 96.

${ }^{89}$ Henry J Steiner, 'International Protection of Human Rights', in Malcolm D. Evans (edn), International Law (3rd edn, Oxford University Press 2010) 784, 799.

${ }^{90}$ Lynn Hunt, Inventing Human Rights - A History (1st edn, WW Norton 2007) 22.

${ }^{91}$ Ibid 119.

${ }^{92}$ McNally (n 5)

${ }^{93}$ Hunt (n 90) 208. 


\section{SLAVERY UNDER THE EUROPEAN CONVENTION ON HUMAN RIGHTS}

The Universal Declaration of Human Rights ${ }^{94}$ (UDHR), which outlaws slavery in Article 4, is seen as evidence of a global consensus on certain values. ${ }^{95}$ The continued existence of slavery and human trafficking, shows that while there might be some (albeit not necessarily universal) consensus that there should be such rights, there is still no consensus as to the enforcement of such rights. Otherwise states would take concerted efforts to free the world's 27 million ${ }^{96}$ slaves. The ideas of humanitarian intervention and the responsibility to protect are not necessarily dead in the water but international action merely for the protection of human rights is still the exception rather than the norm. The problem of human trafficking and slavery could be solved if all states were not only to create but also to enforce laws to outlaw such crimes. The continued existence of such crimes, in particular violence against women, indicates the absence of a true consensus. However, a consensus ${ }^{97}$ is not necessary to find that slavery (and the actions which facilitate it, such as human trafficking and forced prostitution) is absolutely incompatible with the most fundamental human rights. Slavery would also be outlawed if there would not be a single word of positive law in this regard.

It makes one wonder what it says about a world in which these most basic rights are ignored and indeed violated permanently, where unimaginable wealth and suffering exist next to each other. The continued existence of slavery is a disgrace to the international community and all of us. When used for the aim of creating or establishing a situation of slavery, human trafficking is prohibited by jus cogens. ${ }^{98}$ Yet, it continues on a large scale: "Despite the fact that there are many international legal instruments applicable when preventing and combating human trafficking, there are also difficult challenges that need to be overcome in order to achieve appreciable results. ${ }^{.99}$ Only relatively few victims ${ }^{100}$ are identified

\footnotetext{
94 United Nations, Universal Declaration of Human Rights, 10 December 1948, UNTS 999, 302.

95 Norberto Bobbio, Das Zeitalter der Menschenrechte - Ist Toleranz durchsetzbar? (1st edn, Wagenbach, 1998) 9.

${ }^{96}$ Didi Kirsten Tatlow, '27 Million People Said to Live in 'Modern Slavery", in The New York Times, 30 June 2013, available online at http://rendezvous.blogs.nytimes.com/2013/06/20/27-million-people-said-to-livein-modern-slavery/?_r=0.

${ }^{97}$ For the natural law perspective on this issue, see Bobbio, Ibid n 95, 9.

${ }^{98}$ See also Allain (n 84) 550 et seq.

${ }^{99}$ Venla Roth, Defining Human Trafficking and Identifying its Victims - A Study on the Impact and Future Challenges of International, European and Finnish
} 
and a very small number of perpetrators is actually punished. ${ }^{101}$ International law, in particular in Europe, already provides a more than sufficient legal basis to require states to take positive action against human trafficking and slavery. The problem at hand is primarily one of insufficient law enforcement.

Legal Responses to Prostitution-Related Trafficking in Human Beings (2012) 153.

${ }^{100}$ Ibid.

${ }^{101}$ Ibid. 